\title{
GAMBARAN DISTRESS PADA MAHASISWA PREKLINIK TAHUN KETIGA FAKULTAS KEDOKTERAN
}

\author{
Hardisman, Dian Pertiwi \\ Fakultas Kedokteran Universitas Andalas, Padang
}

\begin{abstract}
Background: Learning process in medical school is a big stressor for the students. Many researchers have reported higher distress and related psychological health problems in medical students than in general population and nonmedical students. This study explored how distress affects Indonesian medical students in FMAU, and its association with academic performance and demographic factors.

Method: Cross sectional study was conducted on 185 subjects in the third year medical student of FMAU between AprilMay 2013. Level of stress was measured using Indonesian version of General Health Questionnaire-12 (GHQ-12), with Liker scale indicator (distress is when the score is $>15$ ). Demographic variables such as gender, source of finance, and economic status were assessed in the study. Academic performance was measured by cumulative Grade Point Average (GPA) and last semester GPA. Analyses were done using SPSS.

Results: This study identified 35.7\% of students were in distress, with average GHQ-12 score 13.42+SD4.97. No association was found between admission pathway, academic performance and distress. However, the study revealed that female students had higher risk of distress $(p<0.05)$.

Conclusion: Risk of distress is relatively high in medical students. However, there is no association between demographic factors, academic performance and distress. Further research needs to be conducted to explore risk factors that cause distress of medical students in Indonesian context.
\end{abstract}

Keywords: distress, medical student, academic performance

\section{ABSTRAK}

Latar Belakang: Pembelajaran di kedokteran merupakan stresor berat bagi peserta didiknya. Berbagai penelitian melaporkan angka distress dan masalah kesehatan psikologis relatif tinggi pada mahasiswa kedokteran dibandingkan dengan masyarakat umum dan mahasiswa non-kedokteran. Penelitian ini bertujuan untuk mengeksplorasi gambaran distress pada mahasiswa kedokteran Indonesia (FK-Unand) dan hubungannya dengan nilai akademis dan faktor demografi.

Metode: Studi potong lintang dilakukan pada mahasiswa tahun ketiga FK-Unand dengan 185 responden. Pengumpulan data dilakukan pada bulan April-Mei 2013 setelah mahasiswa mendapatkan nilai Semester-V. Prestasi akademik diukur berdasarkan Indeks Prestasi semester terakhir dan Indeks Prestasi Kumulatif (IPK). Status demografi yang diamati adalah jenis kelamin, status ekonomi dan jalur penerimaan-pembiayaan (reguler dan mandiri). Pengukuran distressmenggunakan General Health Questionnaire-12 (GHQ-12) versi Indonesia, dengan penilaian menggunakan Skala Likert (indikator distress apabila skor >15). Analisis dilakukan dengan SPSS.

Hasil: Rerata skor GHQ-12 adalah 13,42 \pm SD 4,97, dan didapatkan 35,7\% mahasiswa dalam kedaan distress. Tidak ditemukan hubungan antara prestasi akademik dan jalur penerimaan pembiayaan dengan distress yang terjadi. Namun ditemukan bahwa perempuan lebih berisiko distress daripada laki-laki $(\mathrm{p}<0,05)$.

Kesimpulan: Risiko distres pada mahasiswa kedokteran relatif tinggi. Akan tetapi tidak ditemukan hugungan antara faktor-faktor demografi dan prestasi akademik dengan distress. Penelitian lebih lanjut perlu dilakukan untuk mengetahui faktor-faktor penyebab stress secara lebih spesifik pada mahasiswa kedokteran di Indonesia.

Kata kunci: distres, mahasiswa kedokteran, prestasi akademik

Korespondensi: hardisman@fk.unand.ac.id 


\section{PENDAHULUAN}

Stres merupakan respon tubuh yang tidak spesifik terhadap suatu tekanan atau ancaman sebagai upaya untuk melakukan adaptasi. Respon stres ini secara sederhana dikenal dengan istilah fight or flight response, yang berarti respon seorang individu terhadap sesuatu yang dianggapnya mengancam mulai dari 'melawan' sampai kepada 'lari menghindar'. Fight or flight response merupakan mekanisme awal yang dilakukan oleh seseorang secara psikis dan bahkan tanpa melibatkan proses analisis kognisi yang rumit. ${ }^{1,2}$

Jika seseorang menghadapi tekanan psikis yang dirasa kuat, maka melalui proses fight or flight response terjadi beberapa tahapan yang meliputi tahapan kewaspadaan (alarm stage), perlawanan (resistance stage) dan kelelahan (exhaustion stage). ${ }^{3}$ Pada tahap kewaspadaan, seseorang mulai merasakan adanya ancaman atau tekanan psikis, kemudian masuk pada tahap selanjutnya dimana dengan cepat terjadi proses adaptasi yang melibatkan adaptasi psikis dan fisiologis sistem saraf otonom simpatis dengan mekanisme keseimbangan autoregulasi homeostatik. Bila seseorang tidak mampu melakukan proses adaptasi (penyesuaian) maka ia akan masuk pada tahap selanjutnya yaitu tahap kelelahan atau dekompensasi, sehingga terjadi gangguan penyesuaian. Pada tahapan ketiga inilah fase stres dapat dikenal dengan distress. ${ }^{4}$

Terjadinya gangguan penyesuaian (distress) dapat menimbulkan gejala-gejala gangguan psikis dan fisik (psikosomatik) sehingga seseorang tidak lagi mampu menjalankan fungsinya secara optimal secara psikis dan fisik. Gangguan tersebut dapat berupa gangguan tidur, gangguan konsentrasi, gangguan pola makan dan gangguan emosi. ${ }^{1-3,5}$ Jika kondisi ini terjadi pada mahasiswa tentu akan menghambat proses pendidikannya. Selain itu, secara timbal balik, proses pendidikan juga merupakan salah satu penyebab stres (stresor) bagi mahasiswa terutama pada pendidikan kedokteran karena proses pendidikan di kedokteran merupakan stresor yang lebih bagi peserta didiknya. ${ }^{6.8}$ Sehingga dengan demikian, bila mahasiswa mengalami distressakan terjadi hubungan timbal-balik yang terus akan mepengaruhi proses belajarnya.

Berbagai kepustakaan menyebutkan tingginya prevalensi gangguan psikologis yang berhubungan dengan stress pada mahasiswa kedokteran, termasuk gangguan penyesuaian (distress), gangguan kecemassan (ansietas) dan depresi, yang bervariasi dari 12 - 48\% tergantung dari instrumen yang digunakan dan fokus penelitiannya. ${ }^{6,-13} \mathrm{Al}-\mathrm{Dabal}$ et al. ${ }^{6}$ melaporkan tingkat distress pada mahasiswa kedokteran sebesar 48,6\% dengan menggunakan metode identifikasi sendiri terhadap ketegangan psikologis. Gomathi et al. ${ }^{10}$ melaporkan gangguan kesehatan psikologis umum atau distress sebesar 33,6\% dengan menggunakan General Health Questionnaire-12 (GHQ). Gangguan yang lebih spesifik berupa ansietas dilaporkan sebanyak $22 \%$ oleh Siddiqui et al. ${ }^{11}$ dan 28,7\% oleh Ahmed ${ }^{9}$ dengan menggunakan instrument Beck Anxiety Inventory (BAI).Depresi dilaporkan sebanyak 15\% oleh Castadelli-Maia et al. ${ }^{12}$ dan $28 \%$ oleh Ahmed et al. ${ }^{9}$ dengan menggunakan instrumen Beck Depression Inventory (BDI), dan oleh Goebert et al. ${ }^{13}$ sebanyak $12 \%$ depresi mayor dan $9,2 \%$ depresi berat.

Penelitian yang sama belum banyak dilakukan pada mahasiswa kedokteran di Indonesia. Oleh karena itu, berdasarkan tinjauan teoritis hubungan timbal-balik antara beban belajar di kedokteran dengan distress serta hasil berbagai penelitian lain di berbagai pusat pendidikan kedokteran di dunia, maka diperlukan penelitian untuk mengamati hal tersebut di Indonesia. Untuk tahap awal, penulis telah melakukan penelitian untuk melihat bagaimana gambaran distress pada mahasiswa preklinik Fakultas Kedokteran Universitas Andalas, dan hubungannya dengan faktor jenis kelamin, pembiayaan perkuliahan, status ekonomi dan prestasi akademik.

\section{METODE}

Studi ini dilakukan di Fakultas Kedokteran Universitas Andalas (FK-Unand) Padang, dengan pendekatan studi potong lintang (cross sectional). Studi dilakukan terhadap mahasiswa preklinik tahun ketiga agar dapat melihat pola perubahan prestasi akademik. Jumlah responden yang memenuhi kriteria inklusi untuk pengolahan data adalah sebanyak 185 responden dari total populasi sebanyak 268 mahasiswa. Jumlah sampel ini memenuhi kriteria pemilihan sampel minimum dengan perhitungan rumus statistik (minimum 160). Pengumpulan data dilakukan pada bulan April-Mei 2013 ketika mahasiswa telah mendapakan nilai pada semester sebelumnya (Semester V). 
Prestasi akademik ditentukan berdasarkan nilai Indeks Prestasi (IP). Pengelompokkan IP berpedoman pada Peraturan Akademik Program Sarjana Universitas Andalas tahun 2011 dengan membagi IP kepada tujuh kelompok, yaitu $\leq 2,00,2-2,24,2,25-2,74,2,75-3,24,3,25$ 3,49 dan $\geq 3,5 .{ }^{14}$ Berdasarkan pembagian tersebut serta penghargaan terhadap IP lulusan oleh dunia kerja, prestasi akademik dinilai baik bila IP $\geq 2,75$.

Instrumen yang digunakan untuk mengukur tingkat stres adalah General Health Questionnaire-12 (GHQ-12), yang terdiri dari dua belas pertanyaan untuk menilai keadaan stres psikologis sendiri (self assessment) oleh responden. GHQ-12 merupakan instrumen pengukuran skrining untuk gangguan psikologis umum terutama distress, yang valid dan reliabel serta telah digunakan dalam berbagai konteks bahasa. ${ }^{15-21}$ GHQ-12 yang digunakan pada studi ini adalah versi adaptasi bahasa Indonesia yang telah diuji validitas dan reliabilitasnya oleh Idaiani dan Suhardi. ${ }^{22}$ Namun respon skoring yang digunakan mengacu kepada versi asli yang dikembangkan oeh Golberg ${ }^{23}$ dengan membedakan respon pada pertanyaan positif dan negatif (lihat lampiran-1). Skoring yang digunakan pada studi ini adalah skala Likert, dengan rentang kemungkinan hasil 0-36. Nilai batas ambang (cut off point) yang digunakan adalah 11/12 pada populasi umum, dan dikatakan distress bila skornya lebih dari $15 .^{19,24}$
Status ekonomi responden juga dievaluasi berdasarkan batas garis kemiskinan menurut Badan Pusat Statistiik (BPS) yakni kemampuan memenuhi kebutuhan dasar makanan dan bukan makanan yang setara dengan pendapatan perkapita rata-rata di Indonesia Rp.259.520,/bulan untuk akhir tahun 2012. Pendapatan perkapita disesuaikan dengan provinsi dan tempat tinggal asal orang tua. ${ }^{25}$

Data diolah dan ditampilkan secara deskriptif. Untuk melihat hubungan antara faktor demografik dan prestasi akademik dengan tingkat stres yang terjadi dilakukan analisis bivariat.

\section{HASIL DAN PEMBAHASAN}

Dari total 185 responden, terdiri atas 130 orang perempuan $(69,3 \%)$ dan 55 orang laki-laki $(29,7 \%)$, hal ini sesuai dengan karakteristik populasi mahasiswa Fakultas Kedokteran Universitas Andalas khususnya tahun ketiga yang sebagian besar adalah perempuan. Dari segi pembiayaan, dari total 185 responden, 108 orang diantaranya masuk dalam kategori jalur reguler $(58,4 \%)$, sementara 77 orang yang lainnya masuk dalam kategori jalur mandiri (41,6\%). Selengkapnya dapat dilihat pada tabel 1 .

Tabel 1. Sebaran karakteristik responden

\begin{tabular}{llc}
\multicolumn{2}{c}{ Karakteristik } & $\begin{array}{c}\text { Jumah } \\
\mathbf{n}=\mathbf{1 8 5}\end{array}$ \\
\hline \multirow{2}{*}{ Jenis Kelamin } & Laki-Laki & $55(29,7 \%)$ \\
\cline { 2 - 3 } & Perempuan & $130(69,3 \%)$ \\
\hline Jalur Masuk FK/ & Mandiri & $77(41,6 \%)$ \\
\cline { 2 - 3 } Pembiayaan Kuliah & Reguler & $108(58,4 \%)$ \\
\hline
\end{tabular}

Berdasarkan standar pendapatan perkapita tidak ditemukan adanya responden yang berasal dari keluarga miskin, oleh karena itu perlu dilakukan teknik lain dalam mengukur tingkat kemiskinan dan masalah kesulitan keuangan dalam pendidikan untuk penelitian lebih lanjut.
Indeks Prestasi (IP) Semester V dan Indeks Prestasi Kumulatif (IPK) responden hingga saat studi ini dilaksanakan umumnya berada pada rentang 3-3,24 dan 3,25-3,49, dengan rata-rata 3,01 pada IP Semester $V$ dan 3,02 secara kumulatif (lihat Gambar 1). Secara umum, IP semester terakhir dan IPK ini berada diatas 2,75, atau mencerminkan prestasi baik, yang masingmasingnya $81,6 \%$ dan $87,6 \%$ (tabel 2). 


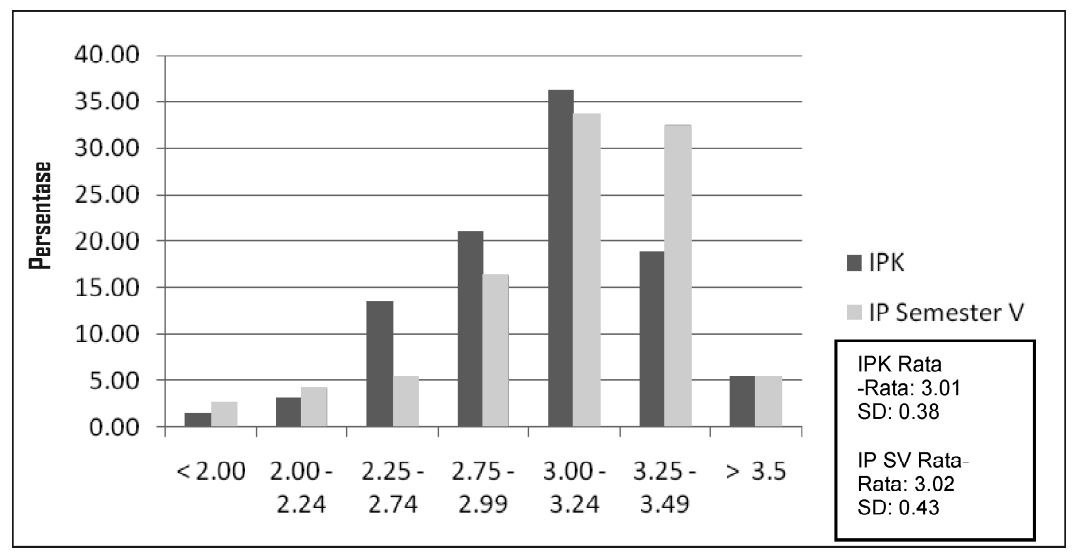

Gambar 1. Grafik sebaran indeks prestasi responden

Tabel 2. Gambaran umum prestasi akademik

\begin{tabular}{llc}
\multicolumn{2}{c}{ Prestasi Akademik } & \multicolumn{1}{c}{ Jumah (\%) } \\
$\mathbf{n = 1 8 5}$
\end{tabular}

Sebaran skor GHQ-12 berada pada rentang 1 sampai 26 , dengan rata-rata $13,42 \pm \mathrm{SD} 4,97$, dimana tiga skor paling sering ditemukan secara berturut-turut adalah skor 10,18 , dan 7 , seperti yang dapat dilihat pada grafik 2 .

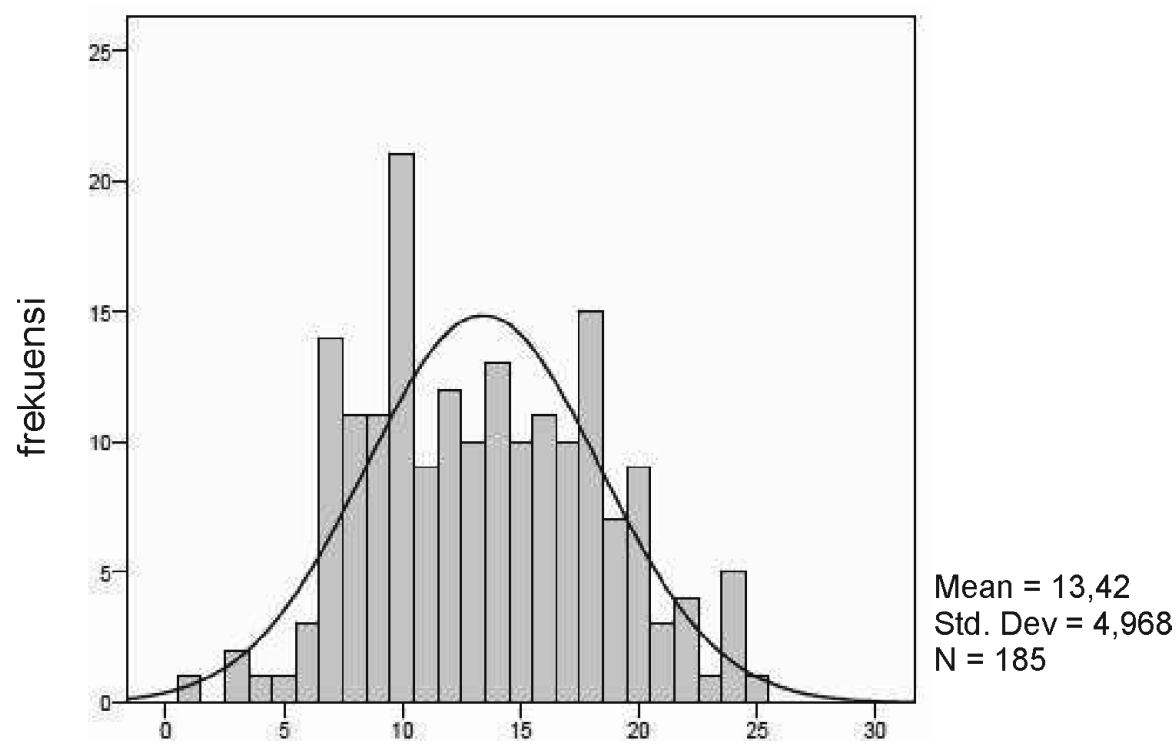

Gambar 2. Grafik sebaran skor GHQ-12 
Nilai rata-rata skor GHQ-12 pada perempuan lebih tinggi dari laki-laki, dan perbedaan ini bermakna secara statistik $(\mathrm{p}<0,05)$. Namun tidak terdapat perbedaan nilai-rata-rata skor antara mahasiswa mandiri dan reguler $(\mathrm{p}>0,05)$.
Berdasarkan prestasi akademik, baik secara kumulatif ataupun prestasi akademik terakhir juga tidak teradapat perbedaan nilai skor rata-rata GHQ-12 ( $\mathrm{p}>0,05)$. Selengkapnya dapat dilihat tabel 3.

Tabel 3. Skor Rata-rata GHQ-12 berdasarkan faktor demografik dan prestasi akademik

\begin{tabular}{|c|c|c|c|c|}
\hline \multirow{2}{*}{\multicolumn{2}{|c|}{ Karakteristik }} & \multicolumn{2}{|c|}{ Skor GHQ -12 * } & \multirow{2}{*}{ Nilai $p^{*}$} \\
\hline & & Rata-Rata & $\pm \underline{\mathrm{SD}}$ & \\
\hline \multirow[t]{2}{*}{ Jenis Kelamin } & Laki-Laki & 12,13 & 4,64 & \multirow{2}{*}{0,021} \\
\hline & Perempuan & 13,96 & 5,01 & \\
\hline \multirow[t]{2}{*}{ Pembiayaan Kuliah } & Mandiri & 13,62 & 4,76 & \multirow{2}{*}{0,633} \\
\hline & Reguler & 13,27 & 5,21 & \\
\hline \multirow[t]{2}{*}{ Prestasi Akademik Kumulatif } & Kurang & 13,00 & 4,50 & \multirow{2}{*}{0,563} \\
\hline & Baik & 13,51 & 5,08 & \\
\hline \multirow[t]{2}{*}{ Prestasi Akademik Terkini } & Kurang & 12,74 & 4,08 & \multirow{2}{*}{0,486} \\
\hline & Baik & 13,51 & 5,08 & \\
\hline
\end{tabular}

${ }^{*}$ Nilai batas ambang risiko distress pada populasi $>11$ dan distress $>15$

${ }^{* *}$ Diolah dengan independent sample t-test, bermakna bila $\mathrm{p}<0,05$

Berdasarkan kriteria distress dari skor GHQ-12 didapatkan $\quad$ kondisi distress, sementara 119 responden lainnya (64,3\%) 66 responden $(35,7 \%)$ mahasiswa tergolong dalam tergolong dalam kondisi normal (tabel 4).

Tabel 4. Sebaran tingkat stres responden

\begin{tabular}{lcc}
\multirow{2}{*}{ Tingkat Stres } & \multicolumn{2}{c}{ Jumlah } \\
\cline { 2 - 3 } Normal & $\mathbf{f}$ & $\%$ \\
\hline Distres & 119 & $64,3 \%$ \\
\hline Jumlah & 66 & $35,7 \%$ \\
\hline
\end{tabular}

Dengan melakukan analisis bivariat, tidak terdapat hubungan antara sumber pembiayaan perkuliahan dan prestasi akademik dengan kondisi kesehatan psikologis. Namun terlihat perempuan lebih cendrung mengalami distress dari laki-laki ( $\mathrm{p}<0,05)$, yakni 54 dari 130 mahasiswi $(41,5 \%)$ mengalami distres, dibandingkan dengan hanya 12 dari 55 mahasiswa $(21,8 \%)$ yang mengalami distres. Selengkapnya dapat dilihat tabel 5. 
Tabel 5. Hubungan faktor demografik dan prestasi akademik dengan tingkat stres

\begin{tabular}{lllll}
\multirow{2}{*}{ Karekteristik } & \multicolumn{2}{c}{ Tingkat Stres } & \multirow{2}{*}{ Nilai p* } \\
\cline { 2 - 4 } Jenis Kelamin & Laki-Laki $(\mathrm{n}=55)$ & $43(78,2 \%)$ & $12(21,8 \%)$ & \multirow{2}{*}{0,010} \\
\cline { 2 - 4 } & Perempuan $(\mathrm{n}=130)$ & $76(58,5 \%)$ & $54(41,5 \%)$ & \\
\hline \multirow{2}{*}{ Pembiayaan } & Mandiri $(\mathrm{n}=77)$ & $50(64,9 \%)$ & $27(35,1 \%)$ & \multirow{2}{*}{0,884} \\
\cline { 2 - 4 } & Reguler $(\mathrm{n}=108)$ & $69(63,9 \%)$ & $39(36,1 \%)$ & \\
\hline Prestasi Kunnulatil & Kurang $(\mathrm{n}-34)$ & $25(73,5 \%)$ & $9(26,5 \%)$ & \multirow{2}{*}{0,215} \\
\cline { 2 - 4 } & Baik $(\mathrm{n}=151)$ & $94(62,3 \%)$ & $57(37,7 \%)$ & \\
\hline \multirow{2}{*}{ Prcstasi Tcrkini } & Kurang $(\mathrm{n}=23)$ & $17(73,9 \%)$ & $6(26,1 \%)$ & \multirow{2}{*}{0,305} \\
\cline { 2 - 4 } & Baik $(\mathrm{n}=162)$ & $102(63,0 \%)$ & $60(37,0 \%)$ & \\
\hline
\end{tabular}

${ }^{*}$ Diolah dengan Chi square, bermakna bila $\mathrm{p}<0,05$

Pada studi ini didapatkan 66 responden $(35,7 \%)$ mahasiswa tergolong dalam kondisi distress, sementara 119 responden lainnya $(64,3 \%)$ tergolong dalam kondisi normal. Studi ini mengkonfirmasi berbagai penelitian dari beberapa kepustakaan bahwa tingginya angka gangguan kesehatan psikologis mahasiwa kedokteran. ${ }^{9,12,13}$ Secara spesifik, hasil ini juga hampir sama dengan penelitian-penelitian yang mengukur tingkat distress mahasiswa kedokteran, seperti oleh $\mathrm{Al}$ Dabal et al. ${ }^{6}$ sebesar 48,6\% dan oleh Gomathi et al..$^{10}$ sebesar 33,6\%. Tingginya angka distress yang ditemukan pada studi ini sesuai dan bersifat memperkuat hasil-hasil penelitian tersebut bahwa beban pendidikan kedokteran menjadi stresor yang cukup berat bagi para mahasiswa kedokteran. Hasil penelitian ini dapat dikatakan cukup linear dengan hasil-hasil penelitian lain. ${ }^{6,10}$

Skor GHQ-12 rata-rata 13,42+SD 4,97 menunjukkan bahwa secara umum tingkat stress mahasiswa kedokteran berada diatas nilai ambang batas (cut off point) dari masyarakat pada umumnya. Hasil ini juga menguatkan penelitian terdahulu bahwa tingkat stres pada mahasiwa kedokteran lebih tinggi dibandingkan dengan nonmahasiswa kedokteran sebagaimana yang dilaporkan oleh Al-Dabal et al., ${ }^{6}$ Fang et al. ${ }^{7}$ dan Ghodasara et al. ${ }^{8}$ Namun ruang lingkup studi ini hanya mencakup satu grup populasi mahasiswa kedokteran dan tidak membandingkan dengan grup mahasiswa lainnya, dalam hal ini mahasiswa non-kedokteran. Relatif tingginya tingkat stres pada mahasiswa FK-Unand yang ditemukan pada studi ini belum dapat menyimpulkan apakah angka ini memang lebih tinggi dari mahasiswa lainnya di perguruan tinggi di Indonesia. Untuk itu penelitian lebih lanjut dan lebih luas sangat perlu dilakukan untuk menentukan tingkat stres mahasiswa FK Unand dibandingkan dengan fakultas kedokteran dari perguruan tinggi lain di Indonesia.

Berbagai kepustakaan menyebutkan relatif tingginya tingkat stres mahasiswa kedokteran dibandingkan dengan non-kedokteran dan masyarakat pada umumnya disebabkan oleh berbagai faktor yang lebih dominan pada mahasiswa kedokteran. Beberapa penelitan telah mengidentifikasi faktor-faktor tersebut seperti beban akademis yang tinggi, ${ }^{10,26,27}$ ketegangan menghadapi ujian, ${ }^{26,28}$ hasil ujian atau prestasi yang kurang ${ }^{26,29}$ dan tidak menyenangi belajar di kedokteran. ${ }^{29}$ Selain itu,kondisi tersebut dapat juga disebabkan oleh faktorfaktor yang berhubungan dengan non-akademis seperti perasaan minoritas, ${ }^{13,30}$ kurangnya dukungan sosial dan lingkungan, ${ }^{12}$ perlakuan yang kurang baik, ${ }^{31}$ masalah keuangan, ${ }^{32}$ serta kepribadian yang perfeksionis atau maladaptif. 33 Berdasarkan temuan ini serta kemungkinan faktor-faktor penyebab tersebut, maka sangat perlu dipertimbangkan analisis kesiapan psikologis dan kepribadian dalam penerimaan mahasiswa kedokteran. 
Semua faktor yang telah dijelaskan oleh berbagai kepustakaan dapat diterapkan dalam studi ini, tetapi lingkup dan keterbatasan penelitian tidak mengeksplorasi faktor-faktor penyebab distress secara lebih luas. Pada penelitian ini juga tidak ditemukan hubungan sumber pembiayaan dan prestasi akademik dengan tingkat stres mahasiswa. Hal ini dapat terjadi karena stres disebabkan oleh berbagai faktor yang saling mendukung. Oleh karena itu perlu dilakukan penelitian lebih lanjut untuk mengeksplorasi faktor-faktor penyebab distress pada mahasiswa FK-Unand secara lebih spesifik.

Pada studi ini didapatkan skor GHQ-12 lebih tinggi pada perempuan daripada laki-laki, tetapi tidak terdapat perbedaan nilai rata-rata skor antara mahasiswa mandiri dan reguler serta antara mahasiswa dengan prestasi akademik yang kurang dan yang baik. Begitu juga halnya apabila dilakukan pengelompokan antara distress dan bukan distress, terlihat perempuan lebih cenderung mengalami distress daripada laki-laki. Studi ini sesuai dengan studi yang dilaporkan oleh Dyrbye et al. pada mahasiswa kedokteran di Amerika Serikat dan Kanada, bahwa secara umum distress dan gangguan psikologis lainnya lebih tinggi pada mahasiswa kedokteran perempuan dari laki-laki. ${ }^{34}$ Keadaan ini mungkin terjadi karena perempuan lebih cenderung tegang dan stres dalam menghadapi ujian dan stresor akademik lainnya, sebagaimana yang dilaporkan Retequiz. ${ }^{35}$ Bahkan secara psikologis umum berdasarkan studi Fitriani dan Hidayah, ${ }^{36}$ perempuan kurang peka terhadap suasana humor dan lebih rentan terhadap distress. Studi ini memberikan implikasi bahwa perhatian dan bimbingan terhadap mahasiswa yang labil secara psikologis dan khususnya perempuan yang bermasalah secara akademik sangat dibutuhkan untuk memastikan tidak terjadi distres yang dapat mengganggu proses pembelajaran mahasiswa dan meningkatkan kualitas belajar dan hasil belajar mahasiswa, terutama mahasiswa kedokteran.

\section{KESIMPULAN}

Angka distress pada mahasiswa Fakultas Kedokteran cukup tinggi, dan secara relatif risiko distress ini lebih tinggi dibandingkan dengan masyarakat pada umumnya. Salah satu penyebab utamanya adalah pembelajaran dan suasana akademik di fakultas kedokteran itu sendiri. Selain itu distress yang terjadi juga disebabkan oleh berbagai faktor akademis dan non akademis yang saling mendukung. Pada studi ini ditemukan bahwa perempuan lebih rentan mengalami distress daripada lakilaki sebagaimana dilaporkan juga pada beberapa penelitian lain, yang dipengaruhi oleh sifat alamiah perempuan.

Oleh karena itu, bimbingan terhadap mahasiswa yang labil secara psikologis dengan masalah akademis sangat perlu dilakukan. Penelitian yang lebih komprehensif perlu dilakukan untuk mengeksplorasi penyebab distres pada mahasiswa kedokteran dengan konteks Indonesia serta kemungkinan gangguan terkait. Lebih lanjut, dengan tingginya beban stress pada pendidikan kedokteran, maka pemeriksaan psikologis sebagai salah satu syarat penerimaan mahasiswa kedokteran sangat direkomendasikan.

\section{UCAPAN TERIMAKASIH}

Terimakasih penulis ucapkan kepada Dekan FK-Unand yang telah mengijinkan penelitian ini dilakukan serta penggunaan data-data akademik mahasiswa, dan kepada Kepala Sub Bagian Akademik dan staf, yang telah membantu memberikan akses terhadap data-data yang diperlukan tersebut. Terimakasih juga penulis ucapkan kepada Azmi Rafhiki dan Erizon staf Medical Education Unit (MEU) FK-Unand yang telah memabantu melakukan pengumpulan data pada mahasiswa. Khusus kepada mahasiswa, penghargaan yang tinggi penulis sampaikan atas kesediannya meluangkan waktu membantu terlaksananya penelitian ini.

\section{PERSETUJUAN ETIKA}

Tidak ada konflik etika pada penelitian ini. Responden bersifat sukarela dan tidak ada keterkaitannya dengan proses pembelajaran mereka, dan tidak ada identitas responden yang disebutkan pada laporan penelitian ini. Instrumen yang digunakan pada penelitian ini (GHQ12) merupakan non-lisenced copy-right, yang telah terdapat luas pada buku-buku rujukan dan jurnal ilmiah, sehingga dapat digunakan dengan hanya menyebutkan sumber kepustakaan. 


\section{DAFTAR PUSTAKA}

1. Mills H, Reiss N, Dombeck M. Stress reduction and management. 2008. Available from: http:// www.mentalhelp.net/poc/view_doc.php?type= doc\&id $=1229 \& \mathrm{cn}=117$.

2. Rice PL. Stress and health. New York: Cengage Learning; 1998.

3. Krohnea HW. Stress and coping theories 2002. Available from: http://userpage.fu-berlin.de/schuez/ folien/Krohne_Stress.pdf.

4. Benton TD, Ifeagwu JA, Aronson SC, Talavera F, Harsch HH, Bienenfeld D. Adjustment disorders 2013. Available from: http://emedicine. medscape.com/article/292759-overview\#showall

5. Richman JA, Flaherty JA. Gender differences in medical student distress: contributions of prior socialization and current role-related stress. Soc Sci Med. 1990;30(7):777-87.

6. Al-Dabal BK, Koura MR, Rasheed P, Al-Sowielem L, Makki SM. A comparative study of perceived stress among female medical and non-medical university students in Dammam, Saudi Arabia. Sultan Qaboos University Medical Journal. 2010;10(2):231-40.

7. Fang DZ, Young CB, Golshan S, Fellows I, Moutier C, Zisook S. Depression in premedical undergraduates:a cross-sectional survey. Primary Care Companion Journal of Clinical Psychiatry [serial on the Internet]. 2010; 12(6). Available from: http:// www.europepmc.org/articles/PMC3067995.

8. Ghodasara SL, Davidson MA, Reich MS, Savoie CV, Rodgers SM. Assessing student mental health at the Vanderbilt University School of Medicine. Acad Med. 2011;86(1):116-21.

9. Ahmed I, Banu H, Al-Fageer R, Al-Suwaidi R. Cognitive emotions: depression and anxiety in medical students and staff. J Crit Care. 2009;24(3):17 .

10. Gomathi KG, Ahmed S, Sreedharan J. Psychological health of first-year health professional students in a medical university in the United arab emirates. Sultan Qaboos University Medical Journal. 2012;12(2):206 13.

11. Siddiqui EU, Naeem SS, Naqvi H, Ahmed B. Prevalence of body-focused repetitive behaviors in three large medical colleges of Karachi: a crosssectional study. BMC Research Notes [serial on the Internet]. 2012; 1(5): Available from: http:// www.biomedcentral.com/1756-0500/5/614.

12. Castaldelli-Maia J, Martins S, Bhugra D, Machado M, Andrade A, C A-S, et al. Does ragging play a role in medical student depression - cause or effect?. J Affect Disord. 2012;139(3):291-7.
13. Goebert D, Thompson D, Takeshita J, Beach C, Bryson P, Ephgrave K, et al. Depressive symptoms in medical students and residents: a multischool study. Acad Med. 2009;84(2):236-41.

14. Universitas Andalas. Peraturan Rektor Universitas Andalas Nomor 7 Tahun 2011 tentang Peraturan Akademik Program Sarjana Universitas Andalas. Padang: Universitas Andalas; 2011.

15. Zulkefly NS. Using the 12-item General Health Questionnaire (GHQ-12) to assess the psychological health of Malaysian college students. Global Journal of Health Science. 2010;2(2):73-80.

16. Hankins $M$. The reliability of the twelve-item general health questionnaire (GHQ-12) under realistic assumptions. BMC Public Health [serial on the Internet]. 2008; 355. Available from: http:// www.biomedcentral.com/1471-2458/8/355.

17. Montazeri A, Harirchi AM, Shariati M, Garmaroudi G, Ebadi M, Fateh A. The 12-item General Health Questionnaire (GHQ-12): translation and validation study of the Iranian version. Health and Quality of Life Outcomes [serial on the Internet]. 2003; 66. Available from: http://www.hqlo.com/content/1/1/ 66.

18. Pevalin DJ. Multiple applications of the GHQ-12 in a general population sample: an investigation of longterm retest effects. Soc Psychiatry Psychiatr Epidemiol. 2000;35(11):508-12.

19. Schmitz N, Kruse J, Tress W. Psychometric properties of the General Health Questionnaire (GHQ-12) in a German primary care sample. Acta Psychiatr Scand. $1999 ; 100(6): 462-8$

20. Shelton N, Herrick K. Comparison of scoring methods and thresholds of the General Health Questionnaire-12 with the Edinburgh Postnatal Depression Scale in English women. Public Health. 2009; 123(11):789 - 93.

21. Baksheev G, Robinson J, Cosgrave E, Baker K, Yung A. Validity of the 12-item General Health Questionnaire (GHQ-12) in detecting depressive and anxiety disorders among high school students. Psychiatry Res. 2011;15(1-2):291-6.

22. Idaiani S, Suhardi. Validitas dan reliabilitas General Health Questionnaire untuk skriningdistres psikologik dan disfungsi sosial di masyarakat. Buletin Penelitian Kesehatan. 2006;34(4):161-73.

23. Goldberg D, Williams P. A users guide to the General Health Questionnaire. Windsor, Berks: NFER Nelson; 1988.

24. Gao F, Luo N, Thumboo J, Fones C, Li S-C, Cheung Y-B. Does the 12-item General Health Questionnaire contain multiple factors and do we need them?. Health and Quality of Life Outcomes [serial on the 
Internet]. 2004; 2. Available from: http:// www.ncbi.nlm.nih.gov/pmc/articles/PMC534792/ pdf/1477-7525-2-63.pdf.

25. BPS. Jumlah dan Persentase Penduduk Miskin, Garis Kemiskinan, Indeks Kedalaman Kemiskinan (P1), dan Indeks Keparahan Kemiskinan (P2) Menurut Provinsi, September 2012. 2012. Available from: http://www.bps.go.id/tab_sub/view.php?kat= 1 \& tabel=1\&daftar=1\&id_subyek=23\& notab=1.

26. Singh R, Goyal M, Tiwari S, Ghildiyal A, Nattu SM, Das S. Effect of examination stress on mood, performance and cortisol levels in medical students. Indian J Physiol Pharmacol. 2012;56(1):48-55.

27. Baldassin S, Silva N, de-Toledo-Ferraz-Alves T, Castaldelli-Maia JM, Bhugra D, Nogueira-Martins $\mathrm{MC}$, et al. Depression in medical students: cluster symptoms and management. J Affect Disord. 2012; In Press.

28. Wong JG, Patil NG, Beh SL, Cheung EP, Wong V, Chan LC, et al. Cultivating psychological well-being in Hong Kong's future doctors. Medical Teacher. 2005;27(8):715-9.

29. Artino AR, La-Rochelle JS, Durning SJ. Second-year medical students' motivational beliefs, emotions, and achievement. Med Educ. 2010;44(12):1203-12.

30. Honney K, Buszewicz M, Coppola W, Griffin M. Comparison of levels of depression in medical and non-medical students. Clinical Teacher. 2010;7(3):180-4.

31. Wolf TM, Scurria PL, Webster MG. A Four-year Study of Anxiety, Depression, Loneliness, Social Support, and Perceived Mistreatment in Medical Students. Journal of Health Psychology. 1998;3(1):125-36.

32. Soh N, Ma C, Lampe L, Hunt G, Malhi G, Walter G. Depression, financial problems and other reasons for suspending medical studies, and requested support services: findings from a qualitative study. Australasian Psychiatry. 2012;20(6):518-23.

33. Enns MW, Cox BJ, Sareen J, Freeman P. Adaptive and maladaptive perfectionism in medical students: a longitudinal investigation. Med Educ. 2001;35(11):1034-42.

34. Dyrbye LN, Thomas MR, Shanafelt TD. Systematic review of depression, anxiety, and other indicators of psychological distress among U.S. and Canadian medical students. Acad Med. 2006;81(4):354-73

35. Reteguiz JA. Relationship between anxiety and standardized patient test performance in the medicine clerkship. J Gen Intern Med. 2006;21(5):415-8.

36. Fitriani A, Hidayah N. Kepekaan humor dengan depresi pada remaja ditinjau dari jenis kelamin. Humanitas. 2012;9(1):76-89. 